\title{
A CITIES: SKYLINES VÁROSÉPÍTŐ SZIMULÁCIÓS JÁTÉK
}

\author{
Hampel György
}

\begin{abstract}
Absztrakt: Szimulációs játékokat régóta alkalmaznak oktatási, tanulási célokra. A játékok vagy játék elemek használatát játékosításnak (gamifikációnak) nevezzük. Egyre színvonalasabb játékok jelennek meg, amelyek alkalmasak arra, hogy elősegítsék bizonyos tudás, vagy képesség elsajátítását és fejlesztését. A 2015-ben kiadott Cities: Skylines városépítő játék a várostervezés számos területén biztosít szimulációs lehetőséget. Erősségei: a település lakóinak és azok mozgásának, a közlekedésnek, valamint a városi közszolgáltatásoknak a modellezése. A programnak létezik oktatási változata is, amelynek segítségével tanulók az oktató irányításával egy város menedzselése során felmerülő problémákat elemezhetnek és oldhatnak meg. Bár a Cities: Skylines a valóságot leegszerüsíti, de ennek ellenére is alkalmas arra, hogy élvezetes módon betekintést adjon egy város tervezésébe, menedzselésébe.
\end{abstract}

\begin{abstract}
Simulation games have been used for educational and learning purposes for a long time. The use of games or game-like elements is called gamification. Published games become better and better; they help people acquire, develop or improve certain knowledge and abilities. Cities: Skylines city-building game published in 2015 provides simulation opportunities in many areas of urban planning. The game is very strong at modelling the behaviour and movement of citizens and modelling transportation or urban public services. Cities: Skylines has an education edition that allows students under the tutor's supervision to analyse and solve problems encountered when managing a city. Although the game simplifies reality, it is still capable of giving an insight into the design and management of a city.
\end{abstract}

Kulcsszavak: játékosítás, szimulációs játék, Cities: Skylines

Keywords: gamification, simulation games, Cities: Skylines

\section{Bevezetés}

Szimulációs játékokat régóta alkalmaznak oktatási, tanulási célokra. Ezek az eszközök a valóság egy részét modellezik annak érdekében, hogy egy általános, átfogó, leegyszerüsített, de ugyanakkor megfelelő képet adjanak egy problémáról vagy szituációról. Arra is alkalmasak, hogy döntések eredményeit valós időben szemléltessék (Haahtela et al., 2015).

A játékosítás, vagy (ahogy szintén elterjedt az angol kifejezés alapján) gamifikáció játékok, ill. játékelemek alkalmazását jelenti az élet játékon kívüli területein. Fő célja, hogy a folyamatokat érdekesebbé, figyelemfelkeltőbbé, eredményesebbé tegye. Egyfajta innovatív oktatási módszernek tekinthető, amely tanulási folyamatokat játékszerüvé alakít. A játékosítás egyik mozgatóeleme, hogy a feladatok elvégzése során, ill. után különbözö formákban megvalósuló jutalmakat kap a ,játékos”. (A gamifikáció fö elemeit lásd az 1. ábrán). Számos területen, így az oktatásban, munkahelyi környezetben, kulturális területeken stb. alkalmazható; helyes alkalmazása minőségi javulással járhat (Lévai, 2015 és Fromann-Damsa, 2016).

Az oktatás játékosítása lehetővé tesz rugalmas tanulási utakat, hallgatóközpontú egyénre szabott tanulást (ugyanaz a célt vagy pontszámot többféle módon is el lehet érni), továbbá önállóságra és felelősségvállalásra is ösztönöz (Lévai, 2015). 
A számítástechnika fejlődésével egyre színvonalasabb (és nagyobb számítási kapacitást igénylö) játékok jelennek meg kifejezetten azzal a céllal, hogy elősegítsék bizonyos tudás, vagy képesség elsajátítását és fejlesztését. Ezek egy része kifejezetten oktatási alkalmazásra készül, ugyanakkor számos nem oktatási célra készült népszerü játék is bizonyítottan alkalmas készségfejlesztésre (FromannDamsa, 2016).

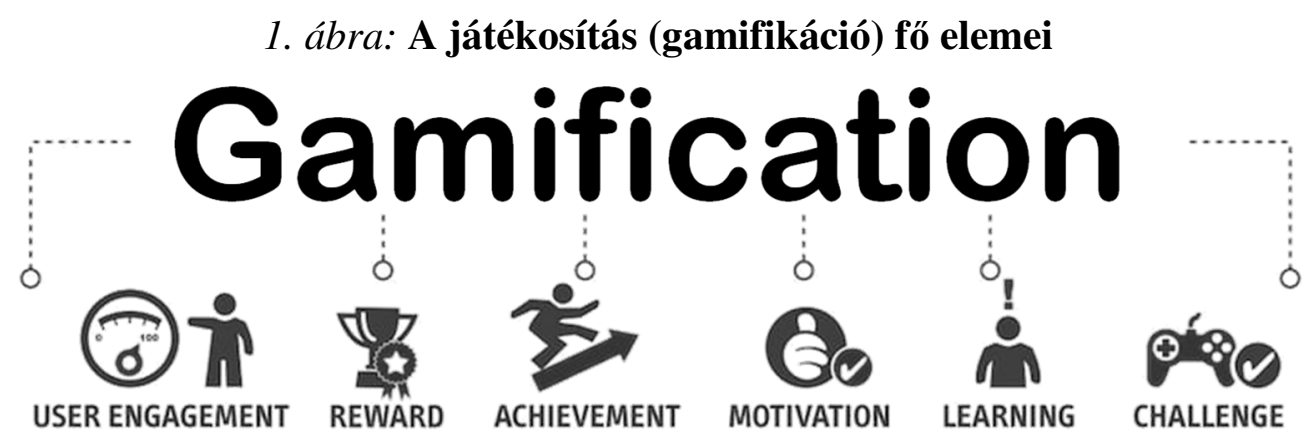

Balról jobbra: felhasználói elkötelezettség, jutalom, teljesítmény, motiváció, tanulás, kihívás.

Forrás: Trueffelpix (é. n.) alapján saját szerkesztés

\section{A játék kiadása, fô jellemzői}

A Cities: Skylines városépítő játékot 2015 márciusában adták ki a Steam tartalomtovábbító és -kezelő rendszeren keresztül (ennek a böngészőből elérhető rendszernek a funkciói közé tartozik - többek között - számítógépes szoftverek digitális áruházi rendszerben történő értékesítése). Azóta számos - interneten keresztül letölthető, a játék fejlesztőitől származó hivatalos - bővítmény (például: After Dark, Snowfall, Natural Disasters, Mass Transit, Green Cities, Parklife, Industries) jelent meg hozzá (2. ábra). Ezek mellett sok, felhasználó által készített kiegészítés is készült a programhoz annak kiadása óta (például: épületek, jármủvek, játékmenet-módosítások stb.) a felhasználói élmény javítása érdekében (3. ábra). A 2015-ös kiadás ellenére még mindig a legnépszerübb és legkelendőbb játékok között foglal helyet (2018. októberi állapot szerint). A program több nyelven elérhető (angolul, németül, oroszul, kínaiul, franciául, spanyolul, portugálul, lengyelül és koreaiul), magyarul (egyelöre) nem tud.

A szimulációs játék első megjelenése óta több platformra is elkészült. Az 1 . táblázat a minimális és ajánlott rendszerkörnyezetet, valamint a cikk írása előtti teszteléshez felhasznált gépek konfigurációját tartalmazza. Nagyon sok felhasználó által készített - kiegészítés telepítése még nagy teljesítményü gépeken sem teszi lehetővé a folyamatos, akadozásmentes (kb. 30 képkocka/másodperc) játékélményt, de ennek fö oka, hogy a játékokat általában nem optimalizálják négynél több processzormagra, ill. a „rajongói tábor” által készített nem hivatalos felhasználói „,mod”-ok sokszor szintén optimalizálás és megfelelő előzetes tesztelés nélkül jelennek meg. 
2. ábra: A Cities: Skylines és fő bővítményei
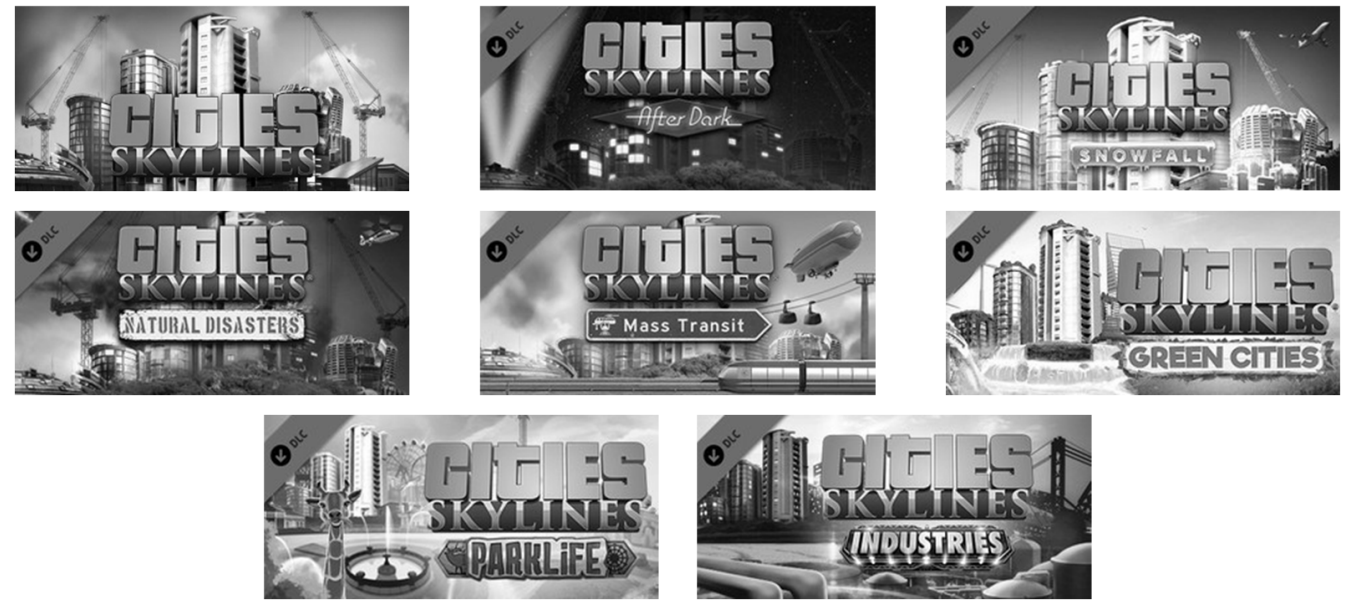

Forrás: Steam (https://store.steampowered.com/app/255710/Cities_Skylines/)

\section{1. táblázat: A program futtatásához szükségesminimális és ajánlott} konfiguráció, valamint a tesztgépek fö adatai

\begin{tabular}{|c|c|c|c|}
\hline Követelmény & Minimum & Ajánlott & Tesztgépek \\
\hline $\begin{array}{l}\text { Processzor } \\
(\mathrm{CPU})\end{array}$ & $\begin{array}{l}\text { Intel Core } 2 \text { Duo, } \\
3 \mathrm{GHz} \text {, vagy } \\
\text { AMD Athlon } 64 \text { X2, } \\
6400+3,2 \mathrm{GHz}\end{array}$ & $\begin{array}{l}\text { Intel Core i5-3470, } \\
\text { 3,20 GHz, vagy } \\
\text { AMD FX-6300, } \\
\text { 3,5 Ghz }\end{array}$ & $\begin{array}{l}\text { Intel Core i9-7900X, } \\
3,3 \mathrm{GHz} \text { és } \\
\text { Intel Core i7-5930K, } \\
3,5 \mathrm{GHz}\end{array}$ \\
\hline $\begin{array}{l}\text { Operatív } \\
\text { memória (RAM) }\end{array}$ & $4 \mathrm{~GB}$ & $6 \mathrm{~GB}$ & $32 \mathrm{~GB}$ \\
\hline $\begin{array}{l}\text { Grafikus kártya } \\
\text { (alaplapra } \\
\text { integrált Intel } \\
\text { HD grafikus } \\
\text { kártya nem } \\
\text { támogatott) }\end{array}$ & $\begin{array}{l}\text { nVIDIA GeForce GTX } \\
\text { 260, } 512 \text { MB, vagy } \\
\text { ATI Radeon HD 5670, } \\
512 \mathrm{MB}\end{array}$ & $\begin{array}{l}\text { nVIDIA GeForce } \\
\text { GTX 660, } 2 \text { GB, } \\
\text { vagy } \\
\text { AMD Radeon HD } \\
7870,2 \text { GB }\end{array}$ & $\begin{array}{l}\text { nVIDIA GeForce } \\
\text { GTX 1080Ti, } 11 \text { GB } \\
\text { és } \\
\text { nVIDIA GeForce } \\
\text { GTX 980Ti, } 6 \text { GB }\end{array}$ \\
\hline $\begin{array}{l}\text { Grafikus } \\
\text { felbontás }\end{array}$ & 640x480 képpont & - & $\begin{array}{l}\text { 3440x1440 és } \\
\text { 2560x1080 képpont }\end{array}$ \\
\hline $\begin{array}{l}\text { Szabad terület a } \\
\text { háttértáron }\end{array}$ & $4 \mathrm{~GB}$ & $4 \mathrm{~GB}$ & $>4 \mathrm{~GB}$ \\
\hline $\begin{array}{l}\text { Internet } \\
\text { kapcsolat }\end{array}$ & Szélessávú & Szélessávú & $\begin{array}{l}\text { Szélessávú } \\
250 \mathrm{Mbit} / \mathrm{s}\end{array}$ \\
\hline $\begin{array}{l}\text { 64-bit-es } \\
\text { operációs } \\
\text { rendszer }\end{array}$ & $\begin{array}{l}\text { Microsoft Windows } \\
\text { XP/Vista/7/8/8.1, OS } \\
\text { X 10.9, } \\
\text { Ubuntu } 12.04\end{array}$ & $\begin{array}{l}\text { Microsoft } \\
\text { Windows } 7 / 8 / 10 \text {, } \\
\text { OS X 10.10, } \\
\text { Ubuntu } 14.10\end{array}$ & $\begin{array}{l}\text { Microsoft Windows } \\
10\end{array}$ \\
\hline
\end{tabular}

Forrás: Steam (2018) alapján saját szerkesztés 


\section{3. ábra: Felhasználói kiegészítések, módosítások}

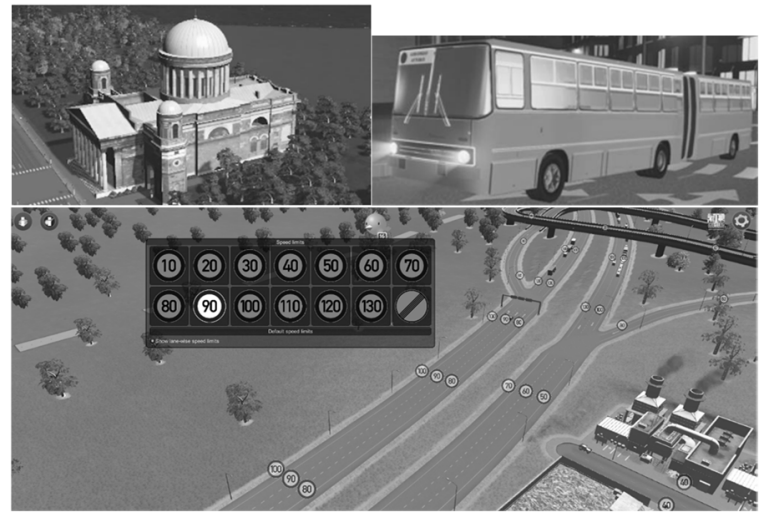

Bal felső kép: Esztergomi bazilika; Jobb felső kép: Ikarus 280; Alsó kép: maximális sebesség beállítása utakon. Forrás: Steam (2018) képernyőmentés

\section{A játék modellezési, szimulációs képességei és céljai}

A Cities: Skylines egyszemélyes játék, ahol a játékos egy fejlődő/fejlesztendő település polgármestereként mindent egymaga irányít. A játék a várostervezés számos területén biztosít szimulációs lehetőséget; ezek a területek kölcsönösen egymásra hatnak, így egy valós, müködő település érzését keltik. A játék erősségei közé tartozik a következők modellezése: (1) a település lakói és azok mozgása; (2) a közlekedés (beleértve a közösségi közlekedést); (3) közszolgáltatások és a szolgáltatásokhoz való hozzáférés, logisztika.

A szimulációs játék elsődleges célja lehet egy város (infrastruktúrájának) építése és a lakosai számának maximalizálása vagy egy szituáció (forgatókönyv) megoldása (például: forgalmi dugók, közlekedési káosz felszámolása) a rendelkezésre álló adókból, hitelekből és egyéb bevételekből származó - költségvetés túllépése nélkül (4. ábra).

\section{4. ábra: Új játék indítása}


Bal oldal: Új játék a környezet kiválasztásával; Jobb oldal: Új játék egy forgatókönyv (probléma) megoldására. Forrás: Cities: Skylines képernyőmentés 
A kitüzött célokat különböző ún. zónák (lakóövezeti, kereskedelmi és ipari) létesítésével (5. ábra) és a megfelelő infrastruktúra (ivó- és szennyvízhálózat, elektromos hálózat stb.) kialakításával (6. ábra), továbbá ezek különböző típusú közúthálózattal, vasúttal, hajóval, légiközlekedéssel történő összekötésével érhetjük el. Az utóbbiak a városból is kivezethetnek biztosítva a más településekkel való összeköttetést.

A lakosság számának növekedésével - és természetesen a megfelelő költségvetés rendelkezésre állása esetén - újabb és újabb épületek, szolgáltatások válnak elérhetővé, amelyekkel tovább bővíthetjük városunkat, ill. növelhetjük a lakosok, valamint a városba (vagy mellé) telepített ipari és kereskedelmi szolgáltatók elégedettségét.

\section{5. ábra: Zónatípusok}

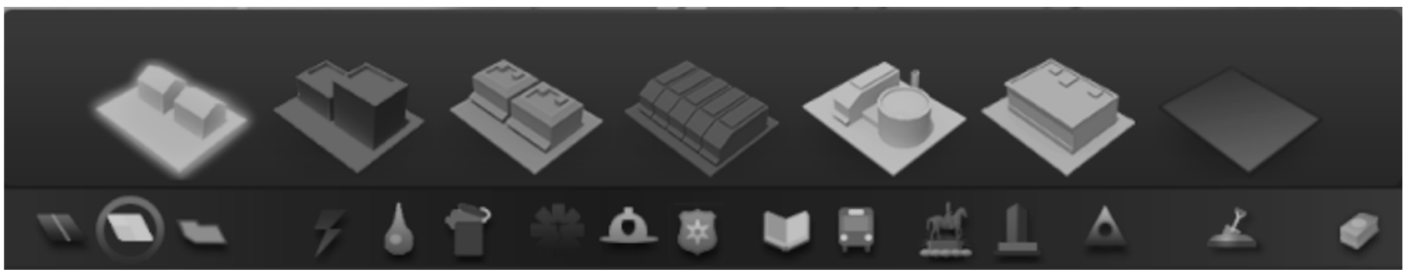

Zónák balról jobbra: lakó (kis és nagy sűrűségű), kereskedelmi (kis és nagy sűrűségű), ipari, irodai Forrás: Cities: Skylines képernyőmentés

\section{6. ábra: Közút, elektromos és vízhálózat}


Forrás: Cities: Skylines képernyőmentés

A városrészek közötti kapcsolatok kialakítása, ill. a lakosok és turisták mozgásának biztosítása érdekében (Zsótér, 2007), vagy ipari/mezőgazdasági 
területek logisztikájának (Lendvai-Nagy, 2017) biztosítására kialakíthatunk busz-, villamos-, metró- és vasútvonalakat (hagyományosat vagy egysínüt), elhelyezhetünk taxiállomásokat, sőt siklókat, kompokat és léghajókat is alkalmazhatunk (7. ábra).

\section{7. ábra: Vasútvonal és metróvonal állomással}
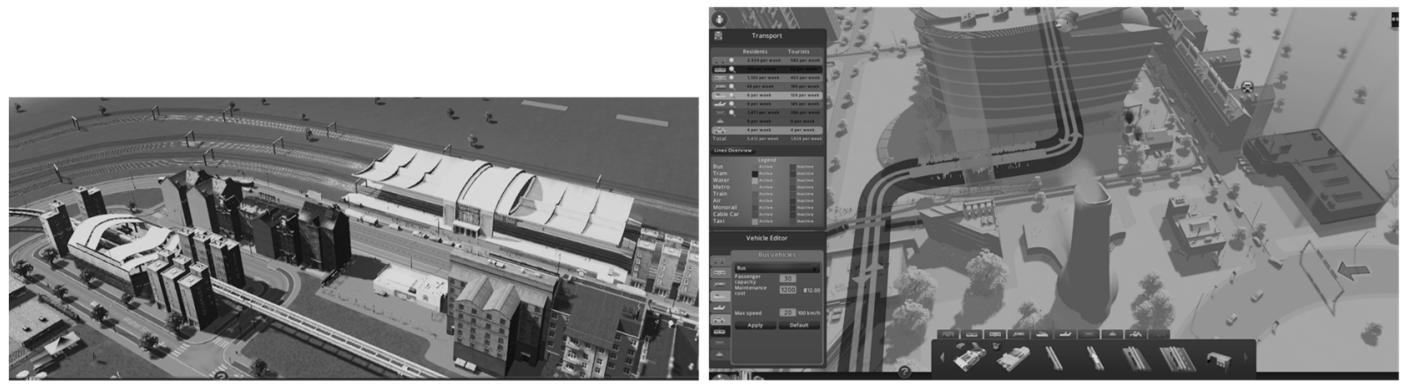

Bal oldal: vasútállomás; Jobb oldal: metró és busz vonalak Forrás: Cities: Skylines képernyőmentés

Középületeket kell emelnünk az oktatás (alsó, közép és felső), a rendőrség, tüzoltóság és az egészségügyi ellátás számára. Rekreációs célokra különböző típusú parkok, szórakozóhelyek létesíthetők. Mindezek kialakítását és fenntartását (Zsótér et al., 2014) szintén a város költségvetéséből kell finanszíroznunk (8. ábra).

\section{8. ábra: Bevételek és kiadások - részlet a városi költségvetésből}

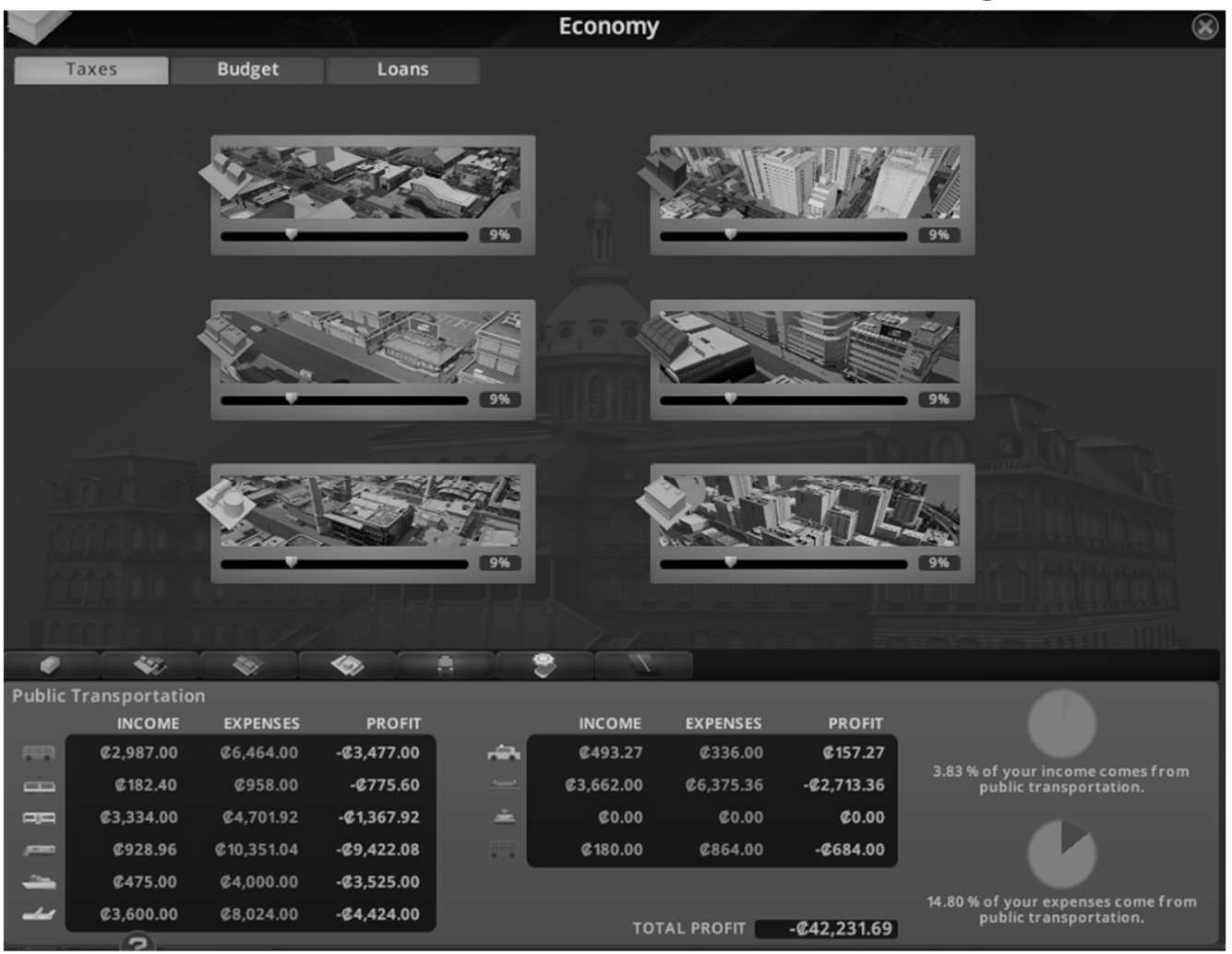

Forrás: Cities: Skylines képernyőmentés 
A városlakók (és a turisták) a rendelkezésre álló közösségi közlekedési jármüvekkel járhatnak munkába, mehetnek bevásárolni, vagy valamilyen szórakozóhelyet meglátogatni. A nehézjármüveket kitilthatjuk lakókörzetekből, a levegőszennyezés elkerülése, csökkentése érdekében pedig ösztönözhetjük az embereket kerékpár és elektromos jármü használatára (9. ábra).

\section{9. ábra: Városi kerületi információk és beállítások}

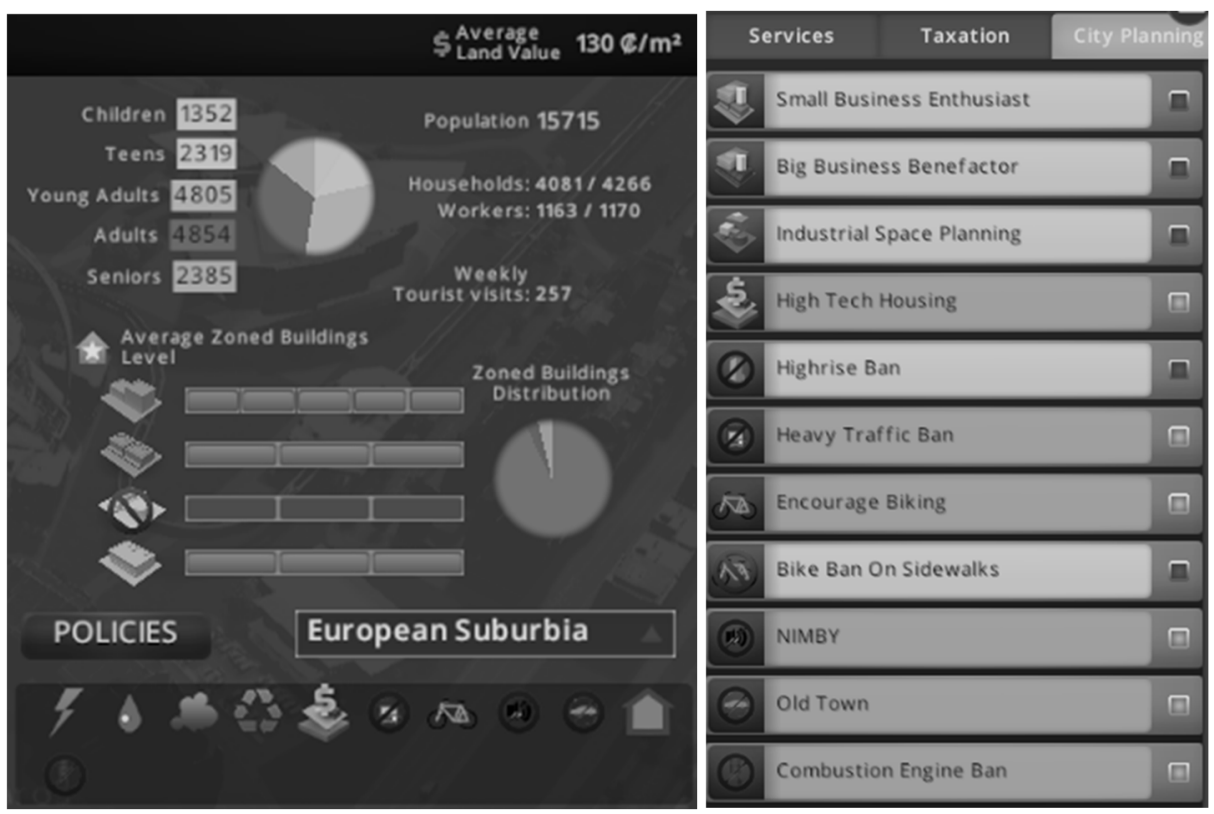

Forrás: Cities: Skylines képernyőmentés

Minden egyes városi szolgáltatás rendelkezik saját költségvetéssel, amelynél külön nappali és éjszakai finanszírozási mérték is beállítható, ha a játékos így látja kívánatosnak (10. ábra). Az útvonalakon a közösségi jármüvek száma egyedileg beállítható (vagy akár automatikussá is tehető) a megállókban állók vagy a jármüveken utazók száma alapján (11. ábra).

A felhasználók által készített és közzétett módosítások lehetővé tesznek számos az úthálózattal kapcsolatos beállítást (például: maximális sebesség az egyes útszakaszokon, sávok iránya az útkereszteződésekben stb., 12. ábra).

Abban az esetben, ha a felhasználó számítógépében megfelelő teljesítményü grafikus kártya áll rendelkezésre, akkor a város és környéke nem csak a magasból figyelhető meg, hanem akár minden egyes jármü, vagy lakos kiválasztható és 3Dben talajszinten is követhetö (13. ábra). 
10. ábra: Szolgáltatások nappali és éjszakai finanszírozása - részlet a városi költségvetésből

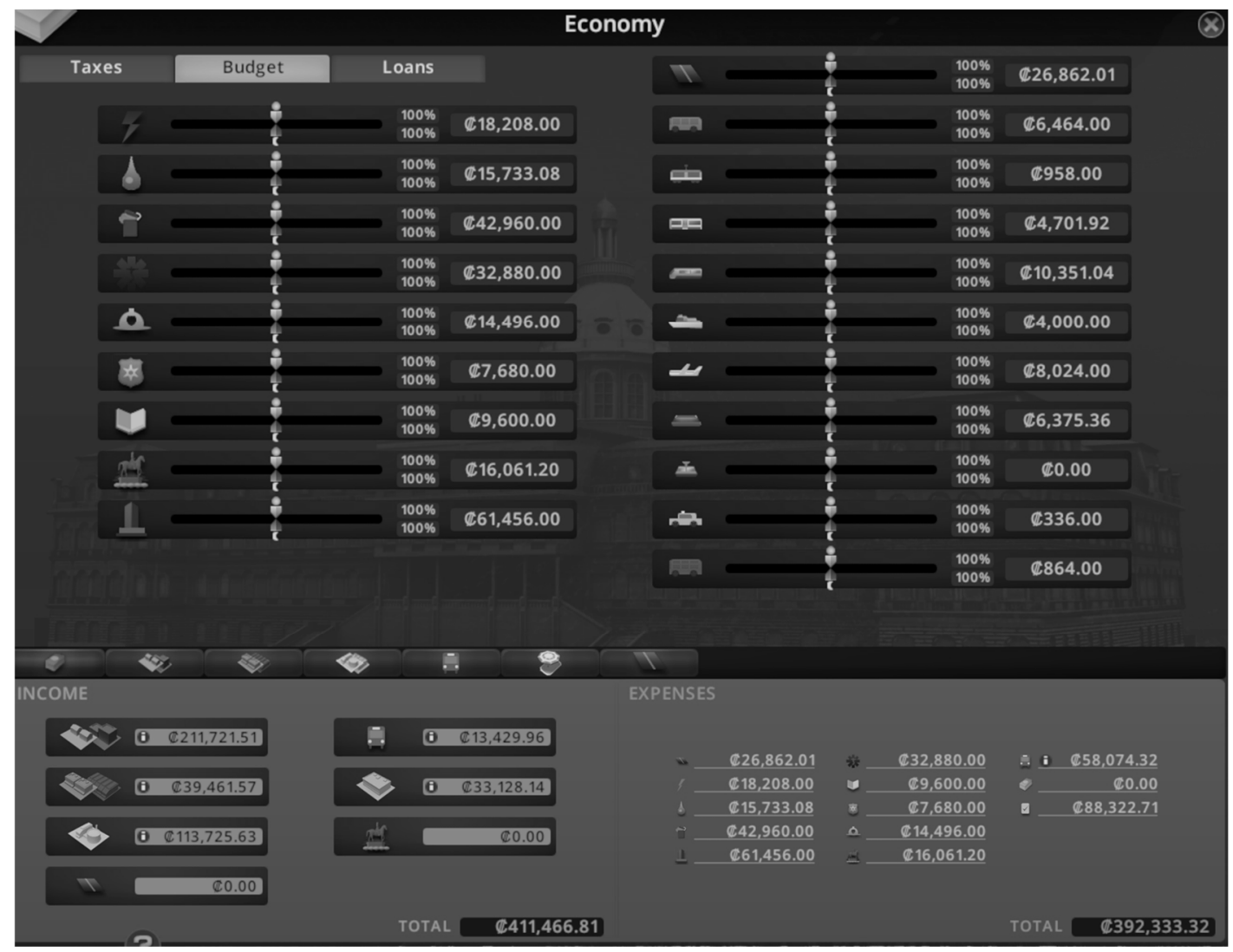

Forrás: Cities: Skylines képernyőmentés

\section{A játék oktatási célú változata}

A Cities: Skylines szimulációs játéknak létezik oktatási változata is (lásd: https://store.teachergaming.com/games/cities-skylines), amely az alapváltozaton felül a Green Cities (Zöld városok) letölthető bővítményt is tartalmazza.

A „teacher gaming” weboldalon (https://desk.teachergaming.com/lessons/ YFiLYus3mjPTKQgEd/solve-pollution) regisztrált felhasználók óravázlatokat (lesson plan) tölthetnek le, amelyek a program adott témájú forgatókönyve (például környezetszennyezés) mellett magyarázatokat tartalmaz (például: mi a cél, amit el kell érni; mi az, amire a játékmenet során célszerú odafigyelni; mit érdemes a tanulókkal az adott témakörben megbeszélni stb.), továbbá külső, az adott témához tartozó forrásokra való hivatkozások is megtalálhatók itt. 


\section{1. ábra: Közösségi közlekedés beállítások}

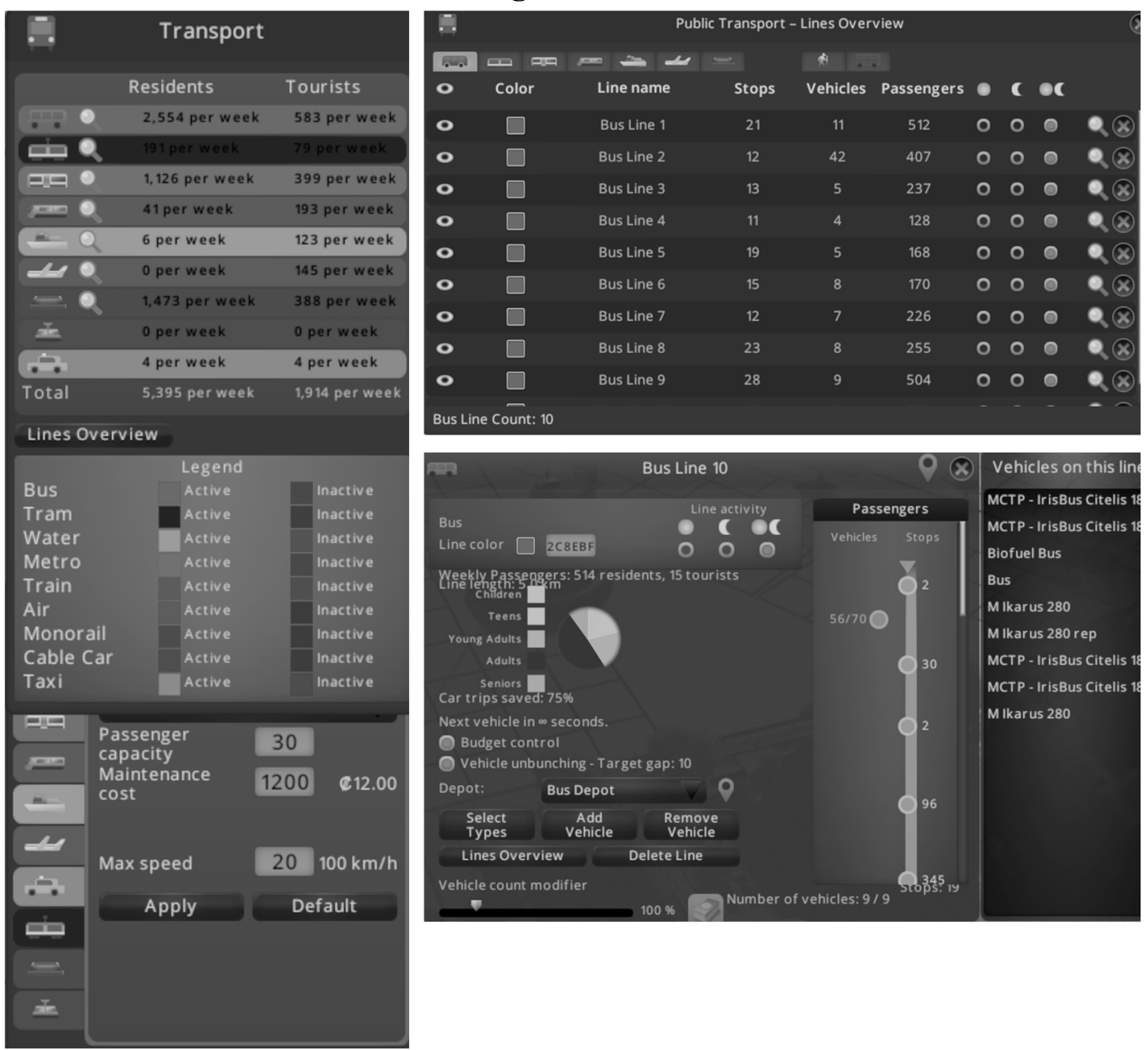

Forrás: Cities: Skylines képernyőmentés

\section{2. ábra: Felhasználói módosítások}



Forrás: Cities: Skylines képernyőmentés 


\section{3. ábra: Madártávlat és 3D utcai nézet}

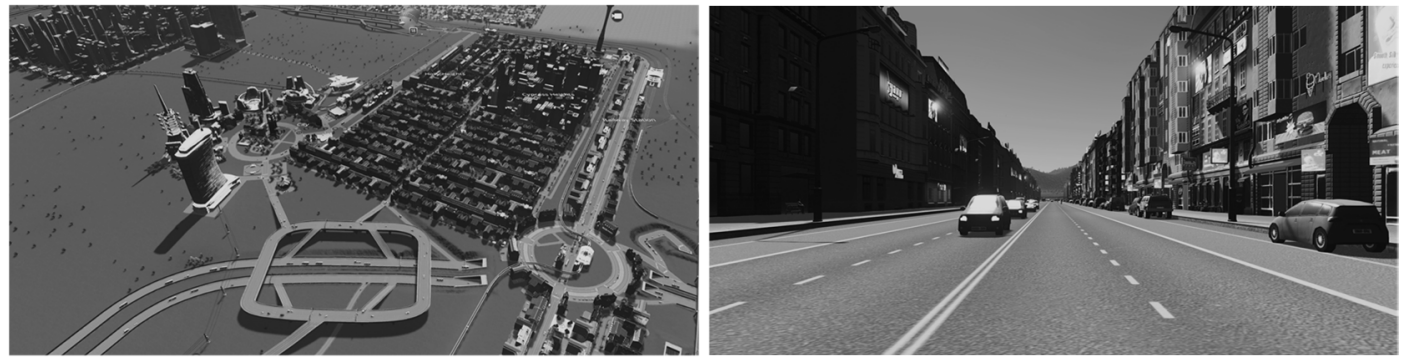

Forrás: Cities: Skylines képernyőmentés

\section{Záró gondolatok}

Azok, akik szeretnek játszva tanulni és tudásukat, képességeiket egy város fejlesztésében és irányításában kipróbálni, remekül fognak szórakozni és emellett sokat fognak tanulni a szimuláció során feltárt összefüggésekből.

A program hardver igényei magasak, egy mai irodai gépen - még ha az korszerünek is tekinthető - a grafikus követelmények miatt jellemzöen nem futtatható.

A játékosoknak a városmenedzselés számos és egymással összefüggő területen kell döntéseket hozniuk, amely döntések aztán kölcsönösen hatnak egymásra. A döntések következményeit a program akár azonnal vagy - a döntés jellegétől és területétől függően - időben később, felhasználónak sokféle információt tartalmazó módon, látványos grafikus ábrázolásokkal mutatja meg.

A Cities: Skylines természetesen a valóság leegyszerüsített modelljét alkalmazza, de az ebből fakadó korlátokkal együtt is alkalmas arra, hogy élvezetes módon betekintést adjon egy város tervezésébe, menedzselésébe.

\section{Irodalomjegyzék}

Fromann R., Damsa A. (2016): A gamifikáció (játékosítás) motivációs eszköztára az oktatásban. Új Pedagógia Szemle, 66 (3-4): 76-81.

Haahtela, P., Vuorinen, T., Kontturi, A., Silfvast, H., Väisänen, M., Onali, J. (2015): Gamification of Education: Cities Skylines as an educational tool for real estate and land use planning studies. Game in Urban Planning, Department of Real Estate, Planning and Geoinformatics Aalto University School of Engineering <https://aaltodoc.aalto.fi/handle/123456789/17843> (2018.10.10.)

Lendvai E., Nagy A. (2017): Egy soltvadkerti szőlőgazdaság logisztikai problémái. Jelenkori társadalmi és gazdasági folyamatok, 12 (3): 231-238.

Lévai Dóra (2015): Játékosítás. TEMPUS Közalapítvány. <https://tka.hu/nemzetkozi/6575/ jatekositas> (2018.10.10.)

Steam <https://store.steampowered.com/app/255710/Cities_Skylines/> (2018.11.19.)

Trueffelpix (é. n.): Gamification. Kép azonosító: 1073188928. Shutterstock $<$ https://www.shutterstock.com/hu/image-vector/banner-gamification-vector-design-conceptkeywords-1073188928?src=HCo1JNgyvjqezzINN2BeAQ-1-0> (2018.10.10.)

Zsótér B. (2007): A Hotel Nonius szolgáltatásait igénybe vevők földrajzi megoszlása. Agrár- és Vidékfejlesztési Szemle, 2 (2): 201-206. 
Zsótér B., Schmidt A., Trandafir, N. (2014): Research of statisfaction related to investments (20062010) accomplished by the local council in Sandorfalva for durable development. Quaestus: Open Access Journal, 5 (3): 107-114. 